\title{
EXPANDING THE BOUNDARIES OF ANTHROPOLOGY: The Cultural Criticism of Gloria Anzaldúa AND MARLON RigGS
}

\author{
RUTH BEHAR
}

For the meeting of the American Anthropological Association in 1992, Lisa Rofel organized an invited panel titled "Expanding the Boundaries: Anthropology and Cultural Critique" focusing on the work of two important cultural critics, Gloria Anzaldúa and Marlon Riggs. Although neither Anzaldúa nor Riggs are anthropologists, they have a good deal to say to anthropologists. As Rofel wrote in her proposal, " $[\mathrm{t}]$ he work of these scholars has helped us to rethink the intersections of gender, race/ ethnicity, and sexuality, and, indeed, to rethink the entire concept of 'culture.' Their writings and productions, as part of 'minority discourse' in the U.S., have provided us with the tools by which to critique anthropology and to move anthropology into a postcolonial, postmodern world." The original plan was for both Anzaldúa and Riggs to be present and for Renato Rosaldo and me to serve as discussants after the screening of Riggs' film Tongues Untied. For reasons of illness, Anzaldúa and Riggs were unable to attend, but to honor their presence even in their absence, I made the introductory remarks which I have expanded upon in this essay, and the Riggs film was screened to a large and enthusiastic audience.

This panel provided the occasion for what I felt was a belated, and very necessary, conversation between American anthropology and the cultural criticism of American minority poet-critics (cf. Freedman 1992). That it was centrally placed on the program of the
Association meetings signaled a historic moment for anthropology. The year 1992 was thick with quincentenary recuperations of the tangled history of encounters, expulsions, and expropriations set in motion by the European conquest of the Americas - a history in which many of anthropology's roots are embedded. It was not only appropriate, but urgent, that 1992 come to stand for the beginning of an anthropological dialogue with the creative scholarship that American people of color have been producing for the last several decades. This is scholarship that, as in the work of Anzaldúa and Riggs, is transforming the very terms and possibilities of cultural representation.

I believe this is an exciting moment for anthropology - crisis and all - because we are becoming aware of our silences; our tongues are starting to be untied. And yet I think we can go farther and should go farther in our selfcritique and in our exploration of other ways of telling anthropological stories. The focus of anthropology on far away cultures made us unaware, until recently, of the internally colonized cultures within this America that we were always leaving behind in search of the Other somewhere else. We traveled back and forth, from our comfortable posts in the American academy to sites across the border, without questioning sufficiently the privileges and exclusions at home that made our work possible in the first place. As Gloria Anzaldúa has stated in an interview, "Even though we are in the United 
States, we're not really of it because we do not partake of the privileges of being white" (Valverde 1988: 30). Many of us become anthropologists precisely because we feel we aren't of it either, or because we don't want to be of it, so we escape to the "exotic" - but let us not forget that there is a world of difference between being able to make this choice and having it thrust upon you because of your color, ethnicity, or class. We need to go beyond our often unpoliticized, static, comfortably-somewhereelse concept of culture and take into account the discriminations of racism, homophobia, sexism, and classism as they occur in the America to which we are always returning to pursue our research agendas.

Anthropology in the United States began here, at home; it has its roots in shame - our shame about the way Native American people have been treated. Fernando Benitez (1970), the Mexican anthropologist, says that ethnographers should communicate their shame to others, for shame is a revolutionary sentiment. In that spirit I want to say some things that I expect will be irritating to the many anthropologists who feel that the current concern with multiculturalism is nothing new to anthropology. The assumption seems to be that since we have always studied the Other, we have somehow, in the animist fashion we used to attribute to primitive mentality, incorporated the insights of multiculturalism into the academic settings in which we practice the profession of anthropology.

Whenever anthropologists want to claim that we've been there already, that anthropology has a long history of confronting racism and countering it with an understanding of cultural diversity, they turn to Franz Boas, the founder of American cultural anthropology. Indeed, early American anthropology, under theguidance of Boas, made an important contribution to undermining racism and creating a stronger national awareness of the destruction of American Indian cultures through conquest. But Boas and his students didn't cover everything and theirs was quite a different time from ours. I don't think that ritually citing this ancestor is going to help us become part of the new discussions surrounding multiculturalism.
If we want ancestors that can be of more direct help to us, I suggest we connect, for a change, with the works of the Native-American ethnographer Ella Deloria and theAfrican-American ethnographer Zora Neale Hurston, both of whom were students of Boas. These anthropologists of color were difficult to place at Columbia - were they native informants or scholars in their own right? Deloria's academic labor was the anthropological equivalent of piece-work: she depended on the patronage of established white scholars and supported herself through short-term contracts. Shewas supposed to be a research assistant to Boas, but he treated her more often as an informant. Deloria chafed against his concern with verification and the documentation of objective truths and told Boas in a letter that "going at it like a whiteman, for me, an Indian, is to throw up an immediate barrier between myself and the people." Deloria found herself needing not only to find other ways of doing fieldwork, but of writing against the grain of established anthropological conventions (Finn in press). Her moving ethnographic novel Waterlily (1988), about the life of a nineteenth-century Dakota woman, was completed in 1944 but not published until forty-four years later. Hurston, too, found herself at odds with the conventions of ethnographic fieldwork practice and writing even though she was, as bell hooks says, "at the cutting edge of a new movement in ethnography and anthropology that has only recently been actualized" (1990: 143). In her ethnography Mules and Men (1990), a pioneering work of self-reflexive writing first published in 1935 , Hurston tells the fascinating story of her return to her hometown of Eatonville, Florida, to study folklore with the "spy glass of anthropology."

Where is Deloria's work, where is Hurston's work, in our canon of anthropology core courses? All the time that anthropologists have been waiting for the natives to talk back, to write their own ethnographies - you know, for the Nuer to just let us have it - we have been strangely unaware that an entire movement of cultural self-representation has been taking place here at home. In anthropology this movement was begun by Deloria and Hurston. But seeing how their voices have been

Ruth Behar teaches ANTHRopology, Women's Studies, and Latina/o StUdies at the UNiverstTy of Michigan, ANn ARbor. She is the aUthor of Translated Woman: Crossing the Border wTth Esperanza's Story (Boston: Beacon Press, 1993). She is also the co-editor, with Deborah Gordon, of Women Wrtting Culture: A Reader

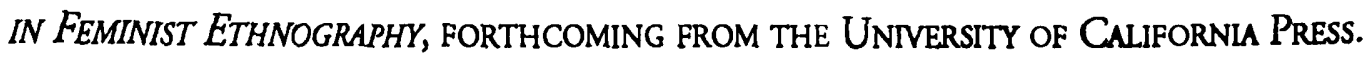


silenced, ignored, marginalized, is it any wonder that the current multicultural movement is unfolding beyond the confines of academic anthropology?

The minority scholars who form part of this movement - key among them Gloria Anzaldúa and Marlon Riggs - are not exactly knocking at our door book "does not address itself primarily to whites, but invites them to 'listen in' to women of color talking to each other and, in some instances, to and 'against' white people" (1990b: xviii). In much the same way, Marlon Riggs' Tongues Untied, a lyrical documentary of gay black culture, was not primarily intended for those

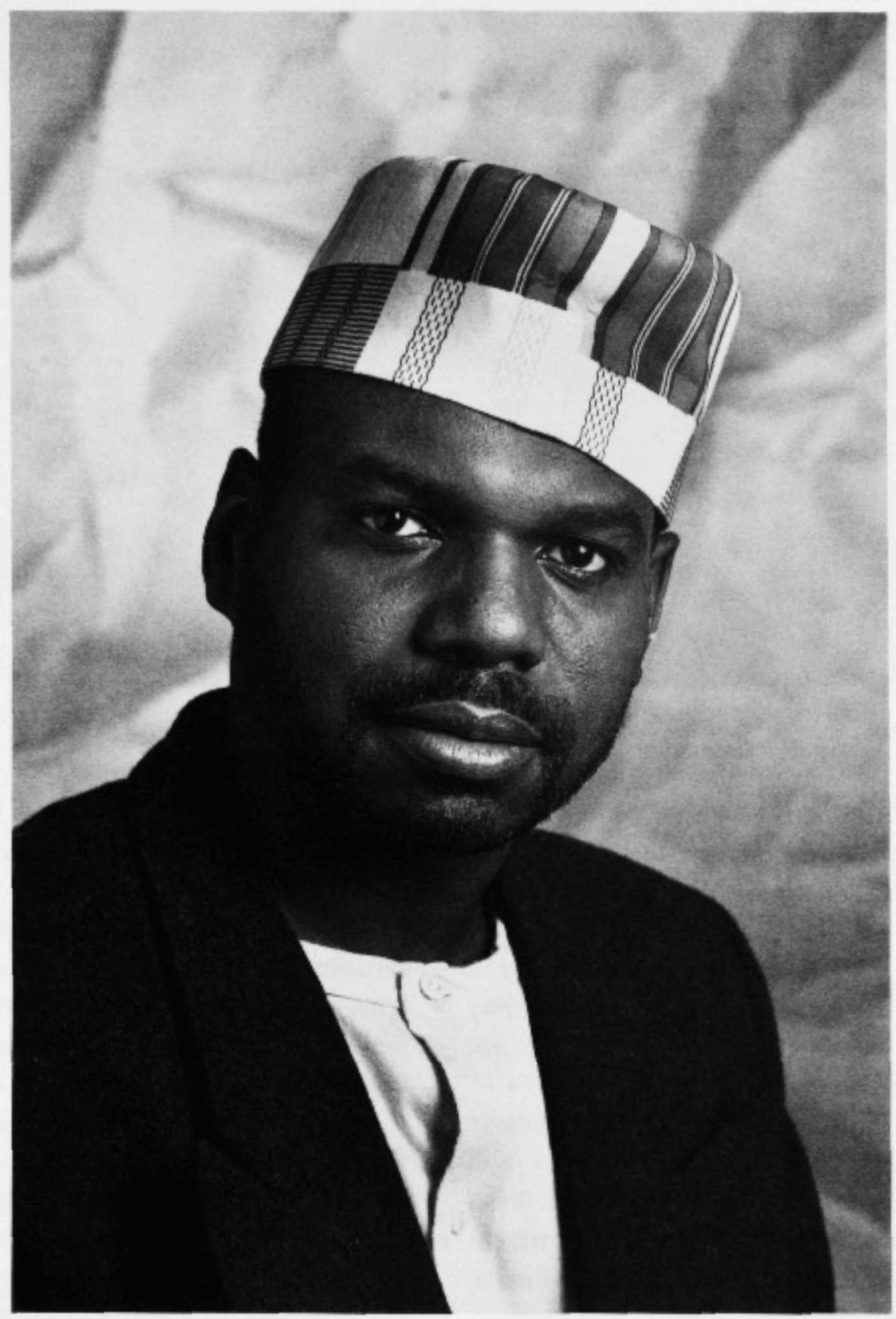

MarLon T. RIGGS

this time around. They don't need our patronage anymore, thankfully. And they don't intend to become our native informants. Or do piece-work for us. As Gloria Anzaldúa notes in the introduction to a new anthology she has edited of the creative and critical work of women of color, titled Making Face, Making Soul, the outside the culture, whether black or white, but for those on the inside. For insiders, the film offered the pleasure of recognition, of being made visible, while for those looking in from the outside, it offers a lesson in the intersection of personal, cultural, and political selfexpression. Let's be clear, though, that this invitation to 


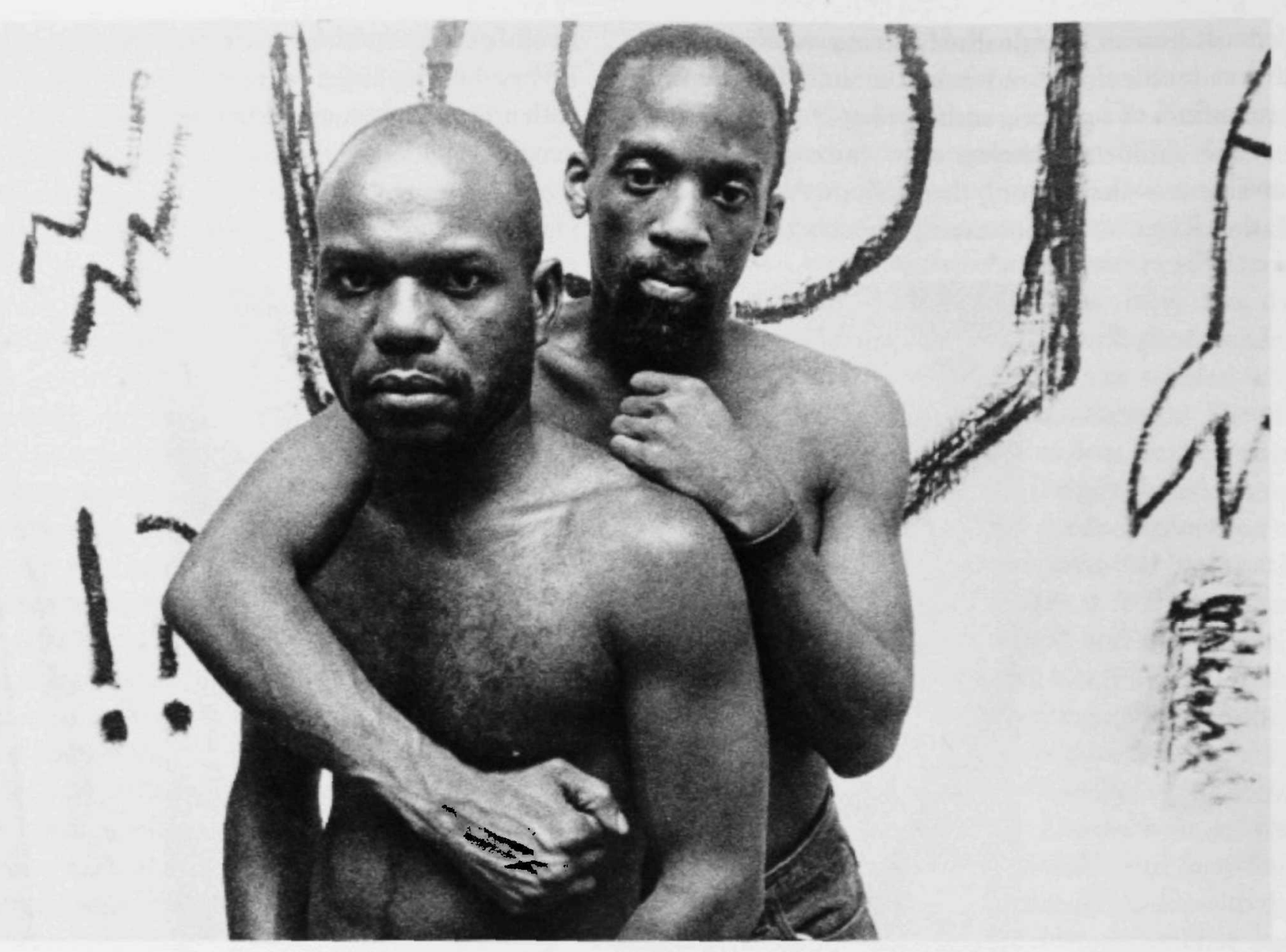

"Tongues Untied."

"listen in" should not be confused with Clifford Geertz's suggestion that we write our cultural texts by reading over the shoulders of the natives. No, this time around anthropologists of color - even those without "proper" credentials - are equal workers in the field of cultural representation, and they are surpassing us in their ability to create new languages for writing culture. They are not waiting for us to construct and represent them.

Having seen the impressive corpus of films made by Marlon Riggs, I was struck by the integrity and thoroughness with which he has approached the issue of how African-Americans are represented, and represent themselves, in popular culture and in the mass media. To know how others have represented you, to unmask the structures of so-called objective representational practices, Riggs shows, is both revolutionary and liberating. While his early video Ethnic Notions explores a wide range of racist images of blacks in American popular culture, his more recent Color Adjustment is a unique history of the representation of black Americans in television programming. As Riggs patiently uncovers one mask after another, showing us both the early demeaningstereotypes of African-Americans in television and the later images, which seek to be "nice" by making African-Americans out to be almost white and almost integrated into mainstream white society, the titles flip across the bottom of the screen, asking "Is this a positive representation?"

Although Ethnic Notions and Color Adjustment are highly original documentaries, they are not as experimental in form as Riggs' more recent videos, Tongues Untied and No Regret, which weave together poetry, performance, autobiography, and historical footage, questioning the limits of what counts as "the document." The tragedy of the AIDS epidemic plays a central role in the newer works. It is AIDS and the losses it has brought about in the black gay community that most forcefully moves Riggs, I feel, to search for ways to untie tongues that urgently need to speak and be heard. And that includes his own tongue. 


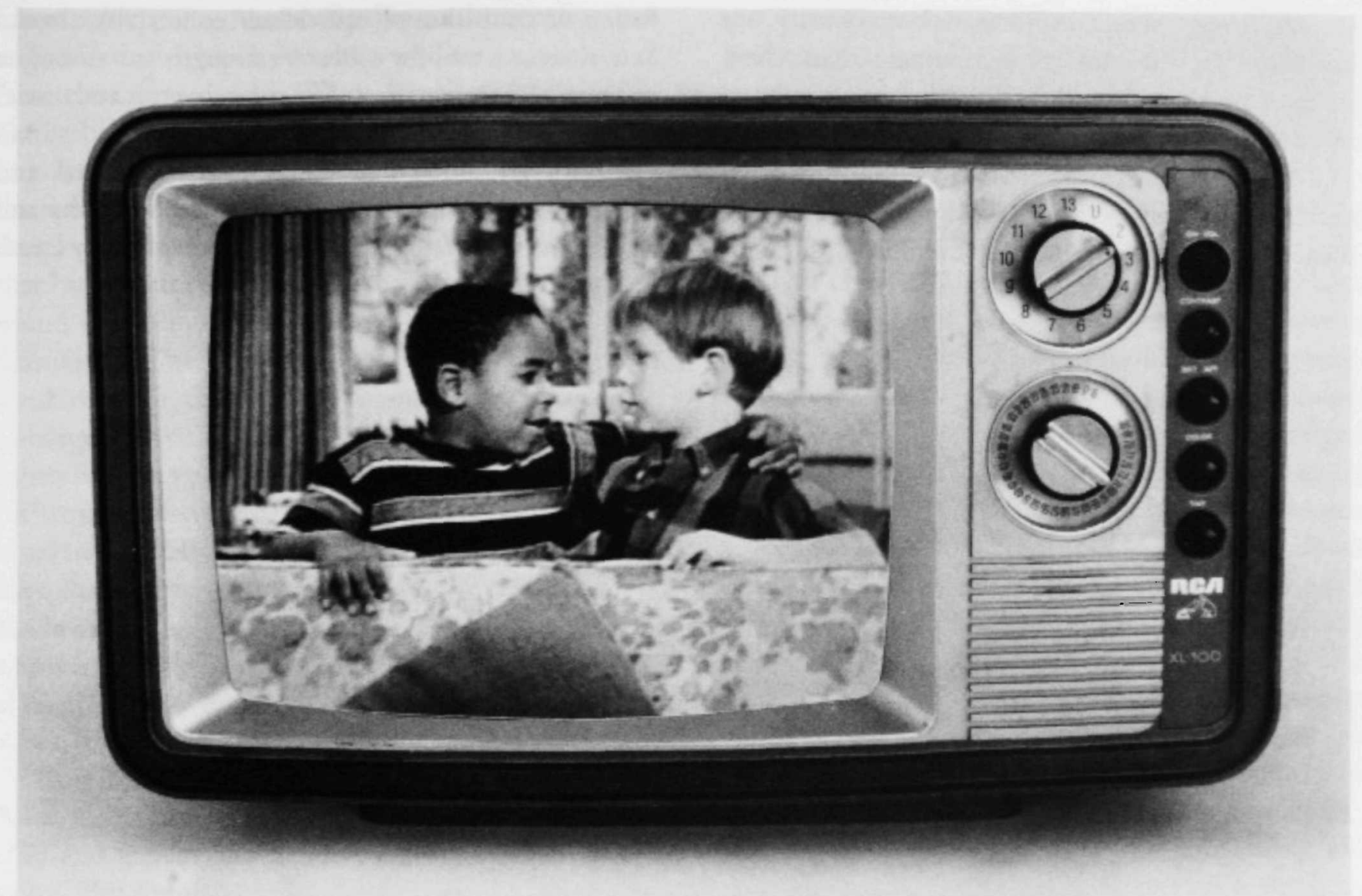

"Color Adjustement."

In his autobiographical film Tongues Untied, as in his moving new film No Regret, a collage of direct statements about their condition by black gay men who are HIV positive, Riggs sets ouc to make his own positive representations, not burdened, but empowered, by the knowledge of the history of representations outsiders have constructed of African-Americans. In Tongues Untied, he takes this history of representations and turns it around, just as he turns around - in a way that is courageously disloyal - the struggle for black civil rights by visually juxtaposing, at the end of the video, the black gay march for freedom with the black political march for freedom of Martin Luther King.

As Riggs has stated in an intervicw, "You need somehow to affirm those gestures which the dominant culture looks down upon and considers inferior or reflecting a flawed personality or a flawed culture. We take that and reverse it.... Some black people are ashamed to dance. White folks will see us and will think, "Well, we're always happy, dancing darkies.' But you have to look at it on your own terms, from your own standard and not continually from eyes of blue. Look through your own eyes and realize that that is a form of cultural resistance, community building, and cultural affirmation . If you do that, then you dance as liberation" (Kleinhans and Lesage 1991: 13). Indeed, in Tongues Untied, Riggs highlights African-American forms of creative selfexpression, including poetry, song, oral storytelling, and dance. It is a visual work rooted, as Riggs has said, in "all the poetry that was coming out by black gay men" (Kleinhans and Lesage 1991: 120). But Riggs does not simply let these poetic voices be heard; he inserts his own voice into the video, producing a multiply voiced work. In addition to telling on camera the story of his own scxual and ethnic coming of age, Riggs appears both in a humorous section on "snap! thology," the practice of finger-snapping among black gay men, and in a section in which he dances together with other participants in his project. Sharing co-authorship with his subjects in Tongues Untied, as few anthropologists are able to do in 
their texts, Riggs not only explores his own identity, but makes room for his subjects to represent themselves, while also participating in a transformative cultural practice with his co-actors (cf. Becquer 1991).

Unlike those who can afford to claim the death of the subject, identity is always a major weapon in the struggles of those who have been internally colonized, those for fusion or confusion of individual/ collectivity around and use it as a tool for collective strength and not as an oppressive representation. We can subvert it and use it" (1990a: 220).

Both Anzaldúa and Riggs join individual and collective concerns by not divorcing ethnography and history from autobiography. In the process, they create

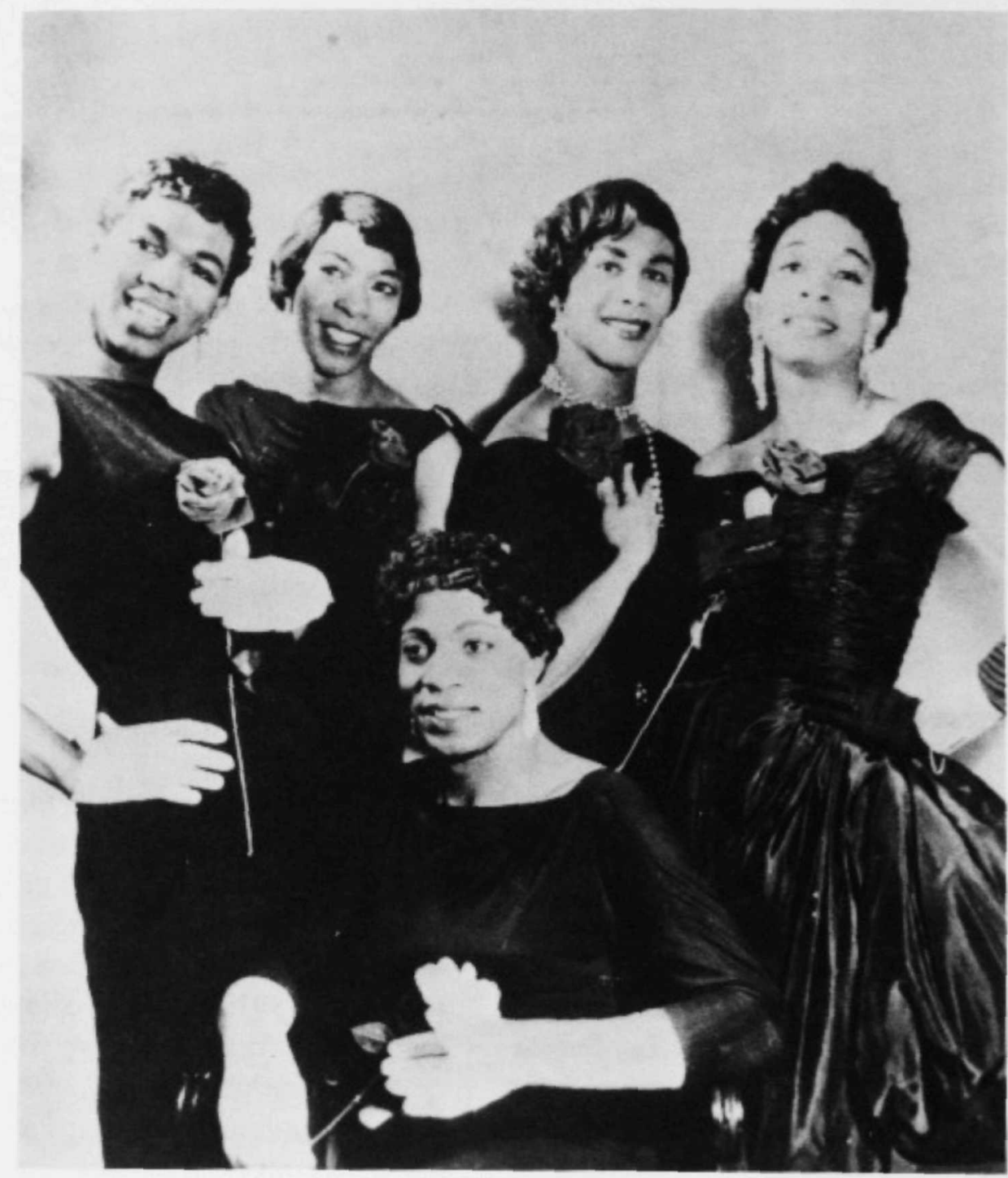

"No Regret."

whom, as Anzaldúa puts it, "the white is still there, invisible, under our skin" (1990b: 145). Anzaldúa has noted that people of color are always being treated generically by the dominant culture; she's been held accountable, she says, for both Richard Rodriguez's antiaffirmative action views and Cesar Chavez's antihegemonic political strategies. But Anzaldúa responds by saying, "I think we people-of-color can turn this new forms of theory, new ways of theorizing, that deacademize theory and connect the community to the academy, new forms that are open, accessible, nonalienating, that allow those who have been left out to come in. Anzaldúa recalls how a Chicana graduate student came sobbing to her once, saying "I don't have the language, the vocabulary." As Anzaldúa notes, this young woman, "like many mujeres of color in graduate 
school, felt oppressed and violated by... a rhetoric disguised as good 'scholarship' by teachers who are unaware of its race, class, and gender "blank spots' (1990b: xxiii). Similarly, Marlon Riggs notes how as a graduate student in journalism he tried to model himself after "the best" the mass media seemed to offer, which was the role of the detached non-participant observer, but he came to realize that "no amount of education would make me look like, sound like, think like, Peter Jennings, Dan Rather, Cronkite.... The truth of my bastard status would always break through, the masks upon masks would ever slip, unhinge" (1991: 8). Only by "stripping off the mascaras others have imposed on us," notes Anzaldúa, is it possible for women of color to become subjects in their own discourses (1990b: xviii). Anzaldúa's notion of refuting false images and mirrors to discover "the unfamiliar shadows" of self-identity is very similar to Riggs' uncovering of layers of representation to get at a nonalienating way of making face. To have face, as Anzaldúa notes, is to have dignity and self-respect (1990b: xxvii).

It is difficult to acquire theorizing space, let alone a voice, in the academic world of scholarship, where race, class and gender are often "blank spots" as Anzaldúa notes. But she also adds, "When we do acquire a voice, we often become periquitas (parrots).... Untied, our tongues run away from themselves" (1990b: xxiii). In finding a language in which to speak, the minority scholar can't help but realize that she or he has made a journey away from home, away from her or his class status. In the words of Anzaldúa again, "Language, fine arts and literature do not belong to women-of-color; culture and the social system enslave our hands in clerical, factory, field or secretarial work.... We are forced to steal a bit of visual, oral, or written languagen (1990b: xxiv). Overcoming legacies of silence, speaking up despite the fear of disclosure, is not only difficult but painful, as Riggs shows; and for a Latina woman, as Anzaldúa reminds us, to have a big mouth, to be repelona, chismosa, is a $\sin$ (1987: 48).

With her book Borderlands/La Frontera, a collection of diverse types of texts - autobiographical, historiographical, theoretical essay, poetry - Anzaldúa became an icon of the new mestiza, a woman whosehybrid sense of identity and location situates her on the border. Borderlands, like Tongues Untied, offers a model for a genre of personal ethnography that explores the interface of the self with a critique of the cultural representations that would limit how that self can be defined. So strong is Anzaldúa's refusal to be translated into the representations of others that she has resisted allowing herself to be labeled a "lesbian" by other lesbians, preferring to be called by the names that resonate for her " and evoke gut feelings and meanings," names like "de las otras" (of the others), jotita, marimacha, loquita, or the Nahuatl patlache (1991: 250). Not only has Anzaldúa reclaimed the names that mark her sexuality as transgressive, she has reclaimed - in an original and breathtaking way theidentity of the mestiza. The idea of mestizaje has roots in colonial Mexico, where it even came to be figured visually in the eighteenth century in a series of paintings that sought to depict the different New World human types combined of Indian, Spanish, and African identity. In the hands of Anzaldúa, mestiza comes to embody her mixed, multiple identity, as she connects with the Indian, the Mexican, and the Anglo-American cultures of her south Texas history. Just as the nationalist movements of the fifties and sixties self-consciously moved away from a hyphenated Mexican-American identity to a Chicano identity, Anzaldúa proposes a new identity, mestiza, that responds both to the continuing social marginalization of Chicanas and serves as a metaphor for non-Chicanas as well (Pérez 1991).

Reclaiming all the bad names they called you at home, all the names that marked you as different, as queer, is equally important for Marlon Riggs, whose talkinglips in Tongues Untied impose a number of names on him and other black gay men, including punk, freak, homo, and fag. Sexuality is the boundary marker, the fence, that divides both Riggs and Anzaldúa from their home communities. While Riggs points out the racism in the white gay community, and in particular the sense of exclusion he felt when he arrived in the Castro district, Riggs does not accept the name "Abomination" that the black church community places on gay sexuality. He refuses to have to make a choice between being black or being gay. As he noted in an interview, "I decided that what I was going to deal with were in some ways explosive yet deeply repressed things in our community. Whether it was taking on the church, or taking on Eddie Murphy, or taking on child sexuality and child sex... That would have to be done. It was either say nothing or go all out" (Kleinhans and Lesage 1991: 124). Anzaldúa likewise refuses to accept the ideology of the male-dominated Chicano movement of the sixties and seventies that 
viewed feminism and lesbianism as white middle-class issues. She will not allow her tongue to be tied by a nationalist anti-feminism (Pérez 1991). "No, I do not buy all the myths of the tribe in to which I was born," she writes (1987: 21-22).

And yet there is the desire to connect with home, despite its blatant homophobia, and there is pain in not being able to go home as who one is - for both Riggs and Anzaldúa. The only way either of them can go home is by transforming home, by remaking it, in their scholarly art, where poetry is always at the center, and by forging new communities made up of exiles like themselves. "If going home is denied me," Anzaldúa writes, "then I will have to stand and claim my own space, making a new culture - una cultura mestiza - with my own lumber, my own bricks and mortar and my own feminist architecture" (1987: 22). In the case of Riggs, after he discovers his invisibility both at home and in the supposed gay mecca of the Castro, he goes in search of some place better, and finds it, in part, in the world of black women's blues - the blues of Billie Holiday and Nina Simone with which he identifies, turning around, crossing over, their unfulfilled desires and yearnings, in the love of black men for each other. As Riggs says, "I love Billie Holiday and Nina Simone. I grew up with these songs. To use them means bringing up stuff from my past. I played those songs over and over as a kid and listened to them as my parents played them.... The Nina Simone song was one I had always loved.... I'd listen to Simone's voice tremble, it'd get so soft and it was so filled with ... I didn't know then why that song had such strong feeling and meaning for me. Now I look back and see obviously why. Her voice is androgynous and could almost play as a man's voice.... I guess I'm very much like many gay men in that some women vocalists are the people whom I most admire and who speak what I feel" (Kleinhans and Lesage 1991: 125). Through this cross-gender identification, Riggs shows that to challenge how and who we are told we can love is to press at the most basic center of human existence.

In Tongues Untied, Riggs gives us a definition of anthropology: that it is the unending search for what is utterly precious. In an essay, he adds that Americans have been watching the crumbling of the Berlin Wall and the dissolution of Soviet power as though we were the victors, standing tall above it all. And yet, he notes, "here at home, our walls, too, are fractured and crumbling.... The myth of what it means to be an American is facing, at last, its own inexorable fate.... What this myth required was the silencing of our most intimate, deepest, life-sustaining truths. It demanded more than mere assimilation; it forced us to view the best within ourselves as the worst, our identities to be jettisoned.... But we are no longer willing to bleed and hence to pay" (1991: 1). Certainly, Riggs has had to pay for his decision to "go all out" and speak disturbing truths. Tongues Untied was scavenged by Pat Buchanan in his presidential ads, Jesse Helms denounced the work in the Senate, and the Christian Coalition sent a sensationalized seven-minute excerpt to all the members of the House of Representatives in a failed effort to control the content restrictions on the N.E.A. (Riggs 1992). Of the fifty stations that had planned to air the film, eighteen dropped it and numerous others rescheduled Tongues Untied at hours way past prime time, from 10 p.m. to as late as 3 a.m. (Saalfield 1991: 5). Yet if Riggs has had to pay for the risks he has taken, the price has been worth it, for he has produced "one of the most sophisticated philosophical and political analyses of race, gender, and sexuality ever put on tape (Kleinhans 1991: 118).

I, for one, am glad that anthropology has ceased to be the sole domain of white Europeans and white North Americans writing about everyone else. I welcome with open arms the emergence of a new discipline without borders that is as much about the complex process of selfrepresentation as about the representation of others. A new discipline that makes the cross-cutting nature of identity its central axis, and a language of poetic criticism its form of expression. A new discipline that explores cultural and gender identity through words, visual images, memory, and music. With Gloria Anzaldúa and Marlon Riggs as guides, I am ready to make this transfigured anthropology my new homeland.

ACKNOWLEDGMENTS. I want to thank Lisa Rofel for organizing the panel where I first presented this essay. My thanks to Tomás Almaguer for an inspiring conversation about the work of Anzaldúa and Riggs that helped me to frame many of my ideas. My thanks to Nancy Lutkehaus for commenting on this essay and suggesting that I revise it for publication in VAR I have a major debt to Gloria Anzaldúa's work and to her example. I could not have done without her concept of the borderlands in thinking through my experience as an anthropologist in Mexico. Actually, I don't think any of us can do without the concept of the borderlands - how 
was anthropology even thinkable without it? Gloria has also inspired me to claim my own mestiza consciousness as a Jewish Latina, who used to try to pass as a second-rate gringa and so was speechless for years about who she is and where she came from.

BIBLIOGRAPHY

Anzaldúa, Gloria

1987 Borderlands/La Frontera: The New Mestiza (San Francisco: Spinsters/ Aunt Lute).

1990a "Bridge, Drawbridge, Sandbar or Island: Lesbians-of-Color Haciendo Alianzas" in Bridges of Power: Women's Multicultural Alliances, edited by Lisa Albrecht and Rose M. Brewer. Philadelphia: New Society Publishers.

1990b Making Face, Making Soull Haciendo Caras: Creative and Critical Perspectives by Women of Color (San Francisco: Aunt Lute Foundation).

1991 "To(o) Queer the Writer - Loca, escritora y chicana" in InVersions: Writing by Dykes, Queers and Lesbians, edited by Betsy Warland (Vancouver: Press Gang Publishers), pp. 249-263.

Anzaldúa, Gloria (ed.)

1990b Making Face, Making Soull Haciendo Caras: Creative and Critical Perspectives by Women of Color (San Francisco: Aunt Lute Foundation).

Becquer, Marcos

1991 "Snap! thology and other Discursive Practices in

Tongues Untied," Wide Angle 13, 2 (April): 6-17. Benítez, Fernando

1970 Los indios de México. (Mexico: Ediciones Era). Deloria, Ella

1988 Waterlily. Lincoln: University of Nebraska Press. Finn, Janet

(in press) "Ella Cara Deloria and Mourning Dove: Writing for Cultures, Writing Against the Grain" in

Women Writing Culture: A Reader in Feminist Ethnography, edited by Ruth Behar and Deborah Gordon. (Berkeley: University of California Press). Freedman, Diane P.

1992 An Alchemy of Genres: Cross-Genre Writing by American Feminist Poet-Critics (Charlottesville:

University Press of Virginia).

hooks, bell

1990 Yearning: Race, Gender, and Cultural Politics (Boston: South End Press).
Hurston, Zora Neale

1990 [1935] Mules and Men (New York: Harper and Row).

Kleinhans, Chuck

1991 "Ethnic Notions, Tongues Untied: Mainstreams and Margins," Jump Cut, 36: 108-118.

Kleinhans, Chuck and Julia Lesage

1991 "Interview with Marlon Riggs: Listening to the Heartbeat," Jump Cut, 36: 119-126.

Moraga, Cherríe and Gloria Anzaldúa (eds.)

1983 This Bridge Called My Back: Writings by Radical Women of Color. New York: Kitchen Table, Women of Color Press.

Pérez, Laura Elisa

1991 "Some Political Problems in Representing Latinas in Literary Criticism and Theory," paper presented at the symposium on Representing the Lives of Women Across Cultures, Center for the Education of Women, University of Michigan, March 11.

Riggs, Marlon

1991 "A Snap! Queen Deliberates: 'Reading' the Media." In Video: The Center for New Television (November/ December): 1,8.

1992 "Meet the New WillieHorton," New York Times Op-Ed, Friday, March 6.

Saalfield, Catherine

1991 "Tongue Tied: Homophobia Hamstrings PBS," The Independent (October): 6-6.

Valverde, Maya

1988 "Borderlands: Transformation at the Crossroads, An Interview with Gloria Anzaldúa." In Woman of Power, 10 (summer): 30-31.

FILMOGRAPHY

Ethnic Notions (1986, 60 min.). By Marlon Riggs. Distrubuted by California Newsreel, San Francisco. Tel. 4156216196.

Color Adjustment (120 min.). By Marlon Riggs. Distributed by California Newsreel, San Francisco. Tel. 4156216196.

Tongues Untied (1989, 55 min.). By Marlon Riggs. Distributed by Frameline, San Francisco. Tel. 415 7038650.

No Regret (30 min.). By Marlon Riggs. Distributed by Frameline, San Francisco. Tel. 4157038650. 